Article

\title{
Modeling Sustainability of Water, Environment, Livelihood, and Culture in Traditional Irrigation Communities and Their Linked Watersheds
}

Alexander Fernald ${ }^{1, *}$, Vincent Tidwell ${ }^{2}$, José Rivera ${ }^{3}$, Sylvia Rodríguez ${ }^{4}$, Steven Guldan ${ }^{5}$, Caitriana Steele ${ }^{1}$, Carlos Ochoa ${ }^{1}$, Brian Hurd ${ }^{1}$, Marquita Ortiz ${ }^{6}$, Kenneth Boykin ${ }^{1}$ and Andres Cibils ${ }^{1}$

1 College of Agricultural, Consumer and Environmental Sciences, New Mexico State University, P.O. Box 30003, MSC 3-I, Las Cruces, NM 88003, USA; E-Mails: caiti@nmsu.edu (C.S.); carochoa@nmsu.edu (C.O.); bhurd@nmsu.edu (B.H.); kboykin@nmsu.edu (K.B.); acibils@nmsu.edu (A.C.)

2 Sandia National Laboratories, P.O. Box 5800, Albuquerque, NM 87185, USA; E-Mail: vctidwe@sandia.gov

3 Center for Regional Studies, MSC 05 3020, 1 University of New Mexico, Albuquerque, NM 87131,USA; E-Mail: jrivera@unm.edu

4 Department of Anthropology (Emerita), MSC01-1040, 1 University of New Mexico, Albuquerque, NM 87131, USA; E-Mail: sylrodri@unm.edu

5 Sustainable Agriculture Science Center at Alcalde, New Mexico State University, 371 County Road 40, P.O. Box 159, Alcalde, NM 87511, USA; E-Mail: sguldan@nmsu.edu

6 New Mexico Acequia Association, 805 Early Street, Building B, Suite 203, Santa Fe, NM 87505, USA; E-Mail: quita@lasacequias.org

* Author to whom correspondence should be addressed; E-Mail: afernald@nmsu.edu; Tel.: +1-575-646-1041; Fax: +1-575-646-5441.

Received: 5 October 2012; in revised form: 2 November 2012 / Accepted: 3 November 2012 / Published: 9 November 2012

Abstract: Water scarcity, land use conversion and cultural and ecosystem changes threaten the way of life for traditional irrigation communities of the semi-arid southwestern United States. Traditions are strong, yet potential upheaval is great in these communities that rely on acequia irrigation systems. Acequias are ancient ditch systems brought from the Iberian Peninsula to the New World over 400 years ago; they are simultaneously gravity flow water delivery systems and shared water governance institutions. Acequias have survived periods of drought and external shocks from changing economics, demographics, and 
resource uses. Now, climate change and urbanization threaten water availability, ecosystem functions, and the acequia communities themselves. Do past adaptive practices hold the key to future sustainability, or are new strategies required? To explore this issue we translated disciplinary understanding into a uniform format of causal loop diagrams to conceptualize the subsystems of the entire acequia-based human-natural system. Four subsystems are identified in this study: hydrology, ecosystem, land use/economics, and sociocultural. Important linkages between subsystems were revealed as well as variables indicating community cohesion (e.g., total irrigated land, intensity of upland grazing, mutualism). Ongoing work will test the conceptualizations with field data and modeling exercises to capture tipping points for non-sustainability and thresholds for sustainable water use and community longevity.

Keywords: interdisciplinary model; sustainability; natural and human system dynamics; hydrology; ecology; economics; culture

\section{Introduction}

In arable valleys of water-limited regions worldwide, community irrigation systems have evolved to maintain community longevity in the face of variable precipitation. In the upper Rio Grande, "acequia" is the Spanish word for the physical and social water management system brought to the New World by the Spanish colonists who migrated from the central valley of Mexico to north-central New Mexico. The word acequia is originally derived from Arabic as-sāqiya, meaning water conduit. These acequia systems have developed complex self-maintaining interactions between culture and nature that enable drought survival and provide many other cultural, ecosystem, and economic benefits. Acequia-centered communities, however, are facing new socioeconomic and natural resource pressures that threaten their ability to maintain the culture and a land-based economy.

\subsection{Threats to Sustainability of Acequia Systems}

In northern New Mexico there are about 800 acequias, and most have been operating for over 200 years, many longer than 300 years [1]. Depending on the acreage served, and size of individual holdings, the member irrigators (called parciantes) in a given acequia may number less than ten or more than 200. Among the threats that acequias are facing today, most are directly or indirectly related to increasing population and urbanization [2-4].

New threats on the horizon derive from climate change and hydrology. Unpredictable and/or limited water supplies are a common challenge faced by community irrigation systems in arid/semiarid areas worldwide. Many climate change scenarios predict less mountain snowpack and earlier runoff for the Southwest/New Mexico [5], and the certainty of future water availability is likely to worsen. Water limitations are further intensifying in the arid and semiarid southwestern United States, due in large part to increasing urbanization. In New Mexico, population increased 13.2\% between 2000 and 2010 [6]. The resulting increase in demand for water is putting increased pressure on acequia 
irrigators and other agricultural water users to sell their water rights and transfer them to the growing urban regions.

Acequias are also threatened when irrigated land is taken out of production. In many communities experiencing population growth, there may be limited private land available for residential development other than that of irrigated fields. Most acequia irrigators have relatively small farms, generally less than four hectares and often less than two. Although crops and livestock can provide an important source of income, some irrigators have decided it is worth more to them to sell their land for residential development than it is to keep it in agriculture. A similar situation was found in Spain [7], where decreased economic viability of small farms has apparently been a factor in a substantial reduction of cultivated area served by community irrigation systems. Because of the very nature of the acequia as a community operated and governed entity, the loss of even a relatively small percentage of irrigators can disrupt the integrity of an acequia and diminish its capacity to maintain its infrastructure and govern its operations.

\subsection{Acequia Communities as Coupled Natural and Human Systems}

Acequia communities are sustained by connections between natural and human elements of irrigated valleys and the upland watersheds they are associated with (Figure 1). Communities use forested uplands for grazing, firewood, timber, hunting, and recreation [8]. Wildlife and livestock travel seasonally from lowland riparian habitat and pastures to upland habitat and meadows. Aquifers buffer water flows at the watershed scale, with flow paths through the mountain that emerge as springs providing streamflow during periods of little snowmelt and rainfall.

Figure 1. Coupled valley and upland watershed showing example connections between elements of surface and groundwater hydrology, community irrigation and land use, grazing of lowland and upland pastures, and wildlife use of valley riparian areas and upland forests.

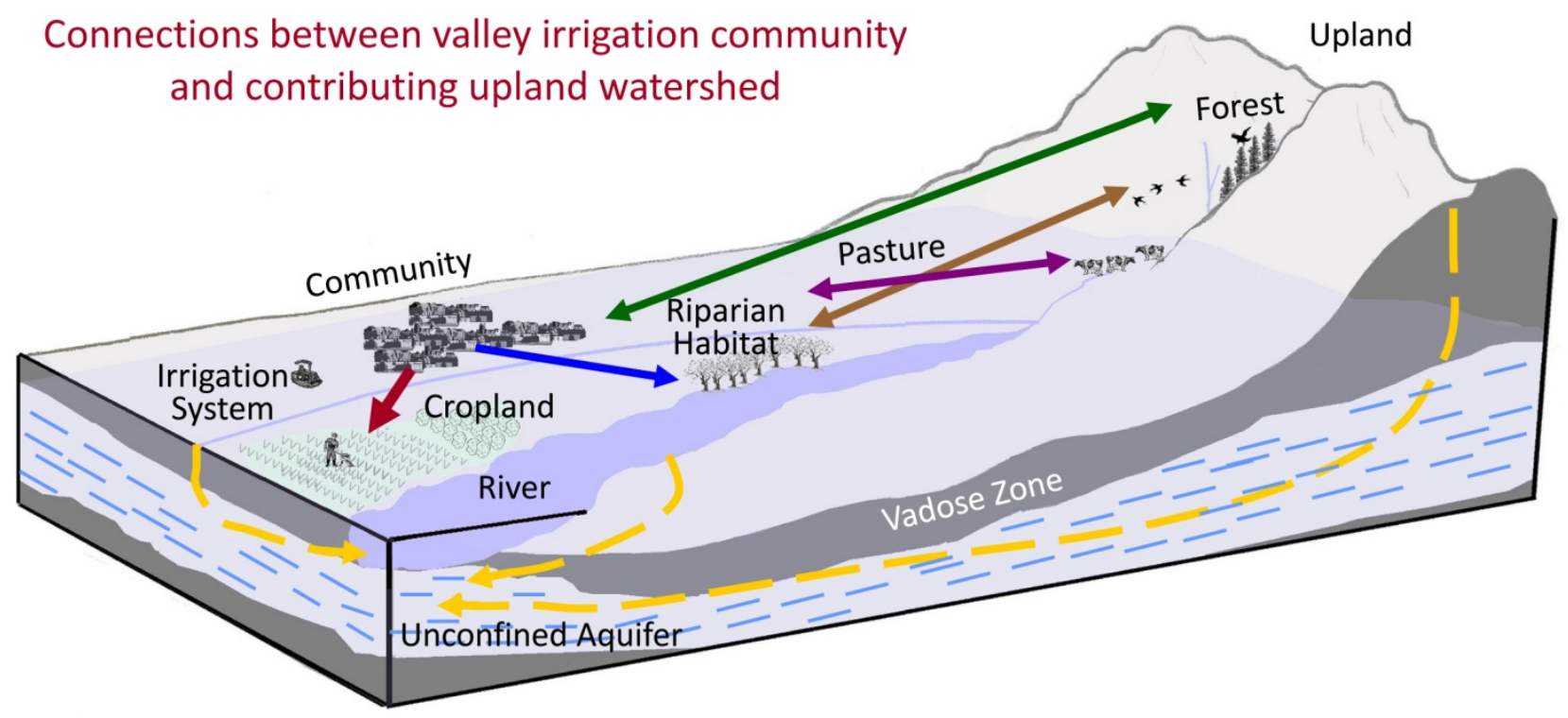




\subsection{High Level Overview of Coupled Systems}

We posit that in the face of population growth and climate change, community resilience is rooted in acequia-based connectivity between natural and human subsystems. Acequia water systems link social, cultural, and economic activities and the natural phenomena occurring within the ecosystem at different scales (Figure 2). The culture, history, and traditions of these acequia systems maintain the identity of the people living in the associated communities and influence their management of land and water to sustain the local economy. In interactions between the acequia systems and natural elements, acequias buffer seasonal hydrologic variation, provide habitat for diverse species, generate ecosystem services (e.g., water quality and return flow), and are greatly affected by local and regional weather conditions (e.g., precipitation and temperature regimes).

Figure 2. Causal flow chart with human and natural linkages through an acequia.

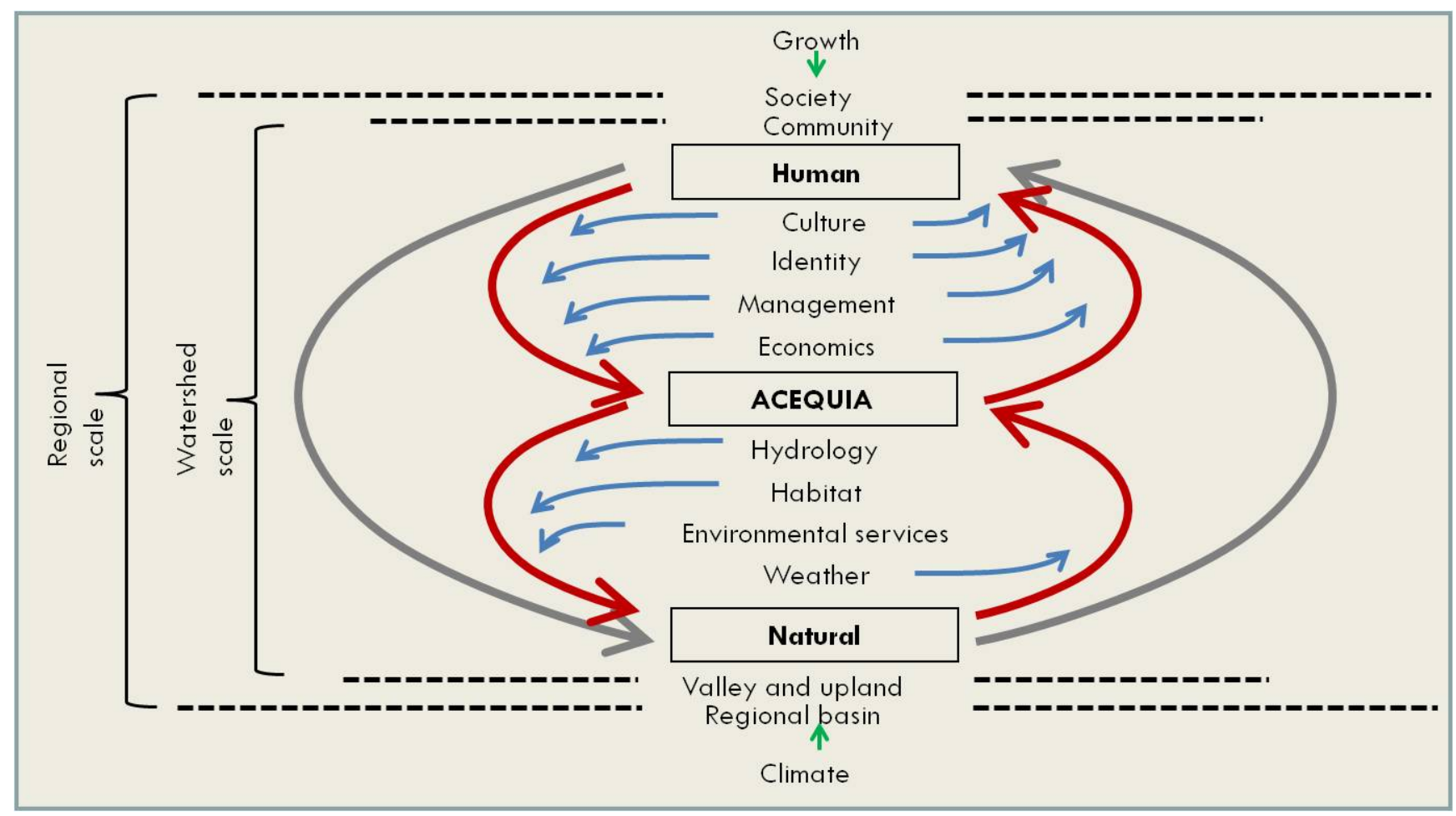

\subsection{Sociocultural Linkages within and between Communities}

Traditional acequia community irrigation systems combine hydrologic and sociocultural strategies to enable responsive community water management. Since the 1920 s, scholars have documented how water is distributed in the rural villages of New Mexico according to rules and regulations embedded in ancient customs and traditions dating to the Spanish colonial settlement periods [4,9-12]. Beyond water management, the community irrigation system provides a nexus of cultural and social continuity, preserving the historic settlements and local cultures spanning major periods of political development from 1598 to the modern period [4]. In many locations, the acequia continues to be the center of village life, maintaining community spirit and engagement. There is a governing commission and mayordomo (canal manager) who are responsible for establishing and implementing a set of rules for maintenance, repairs and water distribution. The annual cleaning of the irrigation ditch not only 
marks the beginning of the agricultural season in early spring but is also an occasion for neighbor irrigators to address local issues. During this ritual event, the ditch officers and irrigators, informally as individuals or in small groups, address a broad range of topics such as the condition of the diversion dam in the river, any repairs that might be needed, the amount of projected water flow based on the winter snowpack at the mountain headwaters, and other items of importance to the ditch or to the community as a whole. By the end of the ditch-cleaning process, the irrigators have renewed their attachment to the land base of their community for yet another irrigation cycle [4].

Adaptability to variable water supply is encoded in acequia customs and culture. The community irrigation ditches have a long tradition of sharing water both in times of abundance and of scarcity, known as repartimiento (water sharing). Coordination between many small communities along one small river is a necessity so that all may have a little water in times of scarcity and plenty in times of abundance [4]. An irrigation sequence is established seasonally and sometimes weekly according to available water supply so that each water user receives his or her full allotment, but no excess. In recent years, however, acequia water has been the target of water markets with potential buyers outside of the acequia communities seeking water for residential development [4]. Transfers outside the acequia community over time can erode both the physical and social functions of the acequia.

\subsection{Hydrologic Connections between Acequia Irrigation Systems, Aquifers, and Rivers}

Acequia irrigation systems connect rivers and shallow aquifers to effectively minimize the range between season peak flows and low flow. Hydrologic budgets of irrigated river valleys reveal that a large percentage of total water diverted for irrigation seeps from canals and percolates below the plant rooting zone. For example, studies indicate that typical canal losses range from $16 \%$ to $43 \%$ of channel flow [13-15], and percolation rates below crop rooting zones as a percentage of irrigation water applied range from less than $23 \%$ to $60 \%$ or more [16-19]. Unlike evapotranspiration losses that take water out of the system and preclude future use, canal seepage and field percolation perform the important function of recharging groundwater as demonstrated with hydrodynamic, chemical, stable isotope, and simulation modeling approaches [19-25]. This water that recharges the shallow aquifer can then become groundwater flow that returns through the subsurface to connected streams [15]. A few studies have addressed this linkage: up to $50 \%$ of irrigation water became groundwater return flow to a river in Montana [26], while field seepage recharge of groundwater provided up to $20 \%$ of total September river flow in Washington [27] and 65\% of wetland inflows in Wyoming [28].

Model simulations of floodplain water management suggest that removal of channel conveyance affects groundwater recharge [29]. System dynamics simulation of scenarios without irrigation diversion and seepage show reduced aquifer returns to the supplying river [29]. Notably, efforts to increase water-use efficiency by reducing canal and field seepage may lead to reduced groundwater recharge and aquifer returns to rivers.

\subsection{Socioeconomic Responses to Changing Water Availability}

Population growth and climate change threaten significant disruption to the rural and agricultural communities of New Mexico [30]. Acequias have been able to adapt to past changes, but the ability of acequia communities to address the range of future challenges is both uncertain and complex. 
For example, there is no adequate historical analogue to the persistent and seemingly ever-increasing water needs posed by growing downstream urban populations. Improved irrigation technology and management can more effectively and precisely provide water (and even nutrients) to growing plants in amounts and with timing that is best suited to enhancing yields. Such increases in water-use efficiency have raised crop yields, changed water use patterns, and perhaps the mix of crops grown. There may, however, be unintended effects on overall water use and water conservation. For example, growing evidence suggests that such technologies and management can increase overall water use as a percentage of applied water [31], thereby impacting water rights and regional water budgets.

Water-related economic assessments of climate change impacts [30] have relied heavily on assumptions of smoothly functioning water markets and low transaction costs. There is, however, little evidence that these assumptions are appropriately applied to small, highly local communities. Although many small communities, such as acequias, may facilitate transfers and trades smoothly within the community with relatively low transaction costs, there may be significant resistance to transfers and trades beyond the community. In the acequia communities of the Southwest, large-scale, market-driven water transfers are often viewed as undesirable and an assault on the community and its environment [32]. In some instances, such transfers are opposed by permitting authorities, such as the Office of the State Engineer in New Mexico, who have broad power to consider the effects of water transfers on the "public welfare" and the "conservation of water" prior to permitting a sale or transfer of water rights [33]. There has been little rigorous evaluation of public welfare in terms of community cohesiveness and structure, adaptive capacity, and ability to plan for and manage changes. Neither has there been complete accounting of the environmental services provided by irrigation system water.

\subsection{Connections between Valley Communities and Their Upland Watersheds}

Very little is known about the dynamic interaction of community irrigation ditches and the natural environment at the spatial scale of regional watersheds. Much of the published literature focuses on irrigation's role in social organization of water users at the local level. The institutional arrangements, labor inputs, collective management, operational rules, sanctions, performance efficiencies, and agricultural cost-benefits of these systems are widely published in literature from around the world. These are described variably as studies of farmer-managed or community irrigation systems, water users associations, peasant irrigation systems, traditional acequia institutions, and by other terms [4,34-37]. More recently, the ecohydrological interactions, environmental values, and multi-functionality of these gravity flow systems have been the subject of new research that requires interdisciplinary approaches by teams composed of hydrologists, ecologists, agronomists, and human culture scientists [15,38-39]. Field-based analysis is still needed at watershed and regional river basin scales in semi-arid environments worldwide.

Agriculture practices that promote heterogeneous habitat types are known to provide conservation benefits in the form of biodiversity [40]. Community irrigation systems have the potential to modify riparian habitat by increasing soil moisture and elevating the water table to enhance native riparian vegetation [15]. Riparian habitats within southwestern United States are diverse systems [41]. Although riparian and aquatic habitats make up less than $1 \%$ of New Mexico land area [42], approximately $80 \%$ of all sensitive vertebrate species depend on them during some portion of their 
life [43]. Of the 867 species of vertebrates known to exist in New Mexico, 479 are dependent on riparian habitat for their survival [43].

Livestock grazing is one of the most important upland activities and is intricately woven into the long-term sustainability of acequias in northern New Mexico [8]. Farmers' livestock typically graze watersheds above the communal irrigation networks; this land use could conceivably influence water quality and irrigation network functions. This tradition of upland-valley linkages can be traced back to the Spanish land grant policies for settlements (Laws of the Indies) that allowed settlers to petition for valley farmland as well as upland forest resources for use as summer grazing of livestock, to insure sustainability of agricultural communities [44].

\subsection{Study Approach}

The purpose of our ongoing research effort is to investigate traditional acequia systems to identify clues to resource sustainability and identify potential adaptation strategies to help these communities persevere. Toward these goals we explore in this paper the complex interactions within this coupled human-natural system. Specifically, we posit that one cannot understand the sustainability of traditional acequia systems without detailed consideration of the interacting subsystems. To explore this tightly coupled system we construct conceptual models for each of four subsystems: hydrology, ecosystem, sociocultural, and land use/economics. Causal loop diagrams (defined below) were used by the project team to develop the conceptual models in a visual and intuitive manner. These causal loop diagrams were also used to vet the conceptual model with stakeholders from acequia communities. Characterization of local knowledge is based on ethnographic observation, self-characterization by community members themselves (including formal and informal interviews), and the ethnohistorical, ethnographic, and popular literature on New Mexican village culture [45-46]. We are, for the first time, actually trying to formulate and test these claims as hypotheses. Ultimately these causal loops and the complex systems they represent will be integrated into a system dynamics model that will help us better understand the magnitude and directionality of the different variables within each subsystem and the interactions among variables in the whole system. This integrated system dynamics model will incorporate past and present information and will be used to try and predict future conditions based on expected changes in population growth and climate variability. This system dynamics model will incorporate community and other interested stakeholder contributions and feedback throughout the entire process and ultimately will be designed to allow stakeholders and policy makers to interact with the model through a series of buttons and sliders (e.g., drought severity) that will generate likely scenarios depending on the user selections.

\section{Methods}

\subsection{Study Sites}

To take advantage of existing instrumentation and networks of local expertise, the interdisciplinary team is working at three detailed study sites: Rio Hondo, a tributary to the Rio Grande main stem; El Rito, a tributary to the Rio Chama and small town of the same name; and Alcalde, which is an acequia on the main stem of the Rio Grande (Figure 3) and a small town of the same name. All sites 
share acequia irrigation tradition, yet they differ in terms of biophysical setting, community size, linkage to uplands, distance to urbanized areas, and age of community.

Figure 3. Study communities (black circles), their associated irrigated valleys (red lines) and contributing watersheds (blue lines).

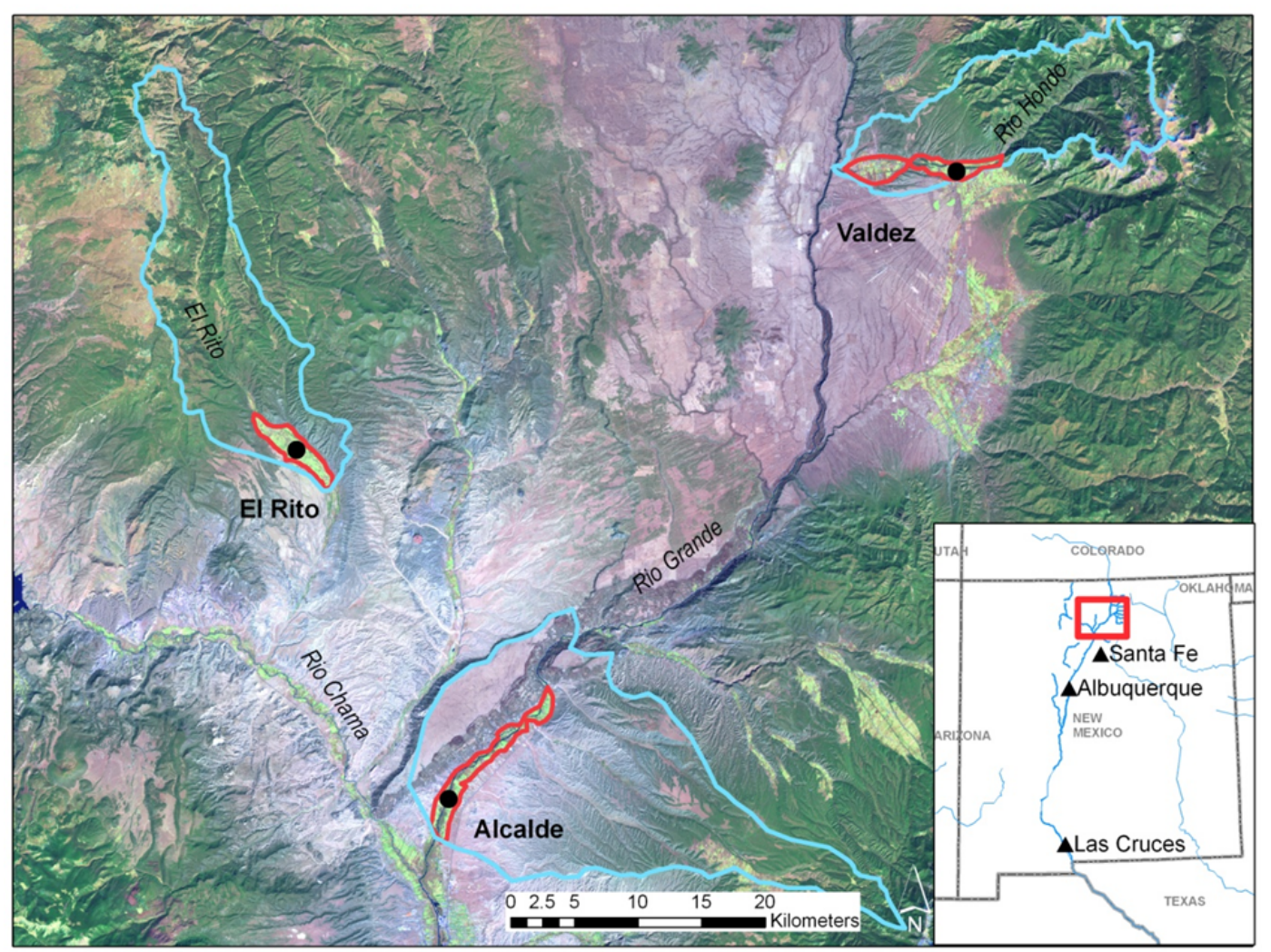

\subsection{Multidisciplinary Modeling Dynamics}

There are several reasons for developing a model of this complex coupled human-natural system. First, a model is needed to quantitatively test hypotheses concerning the resilience of acequia systems. That is, the model will allow us to test hypotheses through simulation and comparison against available social/cultural/physical data. Second, the model will provide a vehicle for structured dialogue with stakeholders. Finally, the model will allow the team to explore alternative futures with the stakeholders to search out potential sustainable pathways for these communities.

Model development is following a four-step process. First, the problem to be solved and the scope of analysis were defined. Second, a description of the system was developed. This step began by conceptualizing the broad structure of the system, followed by decomposing that structure into a series of manageable units defined by specific subsystems (e.g., hydrology, ecosystem, sociocultural, and land use/economics). For each subsystem, a causal loop diagram describing the inherent structure and feedback was developed and reviewed.

These first two steps were first approached through the engagement of our interdisciplinary, multiinstitutional project team. The team includes hydrologists, a cultural anthropologist, a rural development planner, an economist, an ecologist, an agronomist, a remote sensing specialist, a livestock specialist, a community coordinator and systems modelers. Team members have 10-30 years 
of experience in their respective fields. More importantly, team members have extensive experience working with the local and regional communities targeted by this study. Conceptual modeling was accomplished through a full team meeting, phone calls by subsystem theme, diagram preparation at a series of half day face-to-face workshops, development of written descriptions for each subsystem, detailed reworking of diagrams into a common format by the systems modelers, and full team conference calls to go through all text and diagrams.

The work of the project team was then vetted with stakeholders from each acequia community [47]. Specifically, community stakeholders reviewed and evaluated project goals and objectives. Additionally they reviewed the conceptual modeling, adding valuable insight into the operations and functioning of the acequias as well as the communities they support. Ultimately this resulted in the identification of additional variables and connecting links in the causal loop diagrams. This whole process took about 6 months, and was an extremely valuable exercise in practical interdisciplinary research, drawing on the strengths of each discipline while finding previously unidentified linkages between the subsystems.

In the third step of the modeling process (not completed at the time of this writing), the causal loop diagrams are being converted into a system dynamics context, and model sectors are being populated with appropriate data and mathematical relations. The modelers are largely responsible for conversion of the causal relations while the rest of the multidisciplinary team is working to identify data and parameters necessary to quantify the key processes. The intent is to have a working model early in the project to encourage dialogue with the stakeholders and across the team.

Step four involves model calibration against field and historical data followed by review. This step depends simultaneously on disciplinary expertise and the integration of that expertise into the integrated model. The integrated model also allows the multidisciplinary team to explore feedback across disciplines, thus challenging understanding about how the various subsystems interact and influence one another. In terms of community input, the model provides a vehicle for stakeholders to match model performance against their historical experience. Collective review by experts and stakeholders of the model conceptualization and the model performance provides powerful input for model focus and calibration [48]. Ultimately, the last three steps will be iterated several times during the course of the project.

There are a number of commercially available, object-oriented simulation tools that provide a convenient environment for constructing system dynamics models. For purposes of this project, Studio 8, produced by Powersim, Inc., is used [49]. With this tool, model construction proceeds in a graphical environment using objects as building blocks. These objects are defined with specific attributes that represent individual physical or social processes, and are networked together so as to mimic the general structure of the system, as portrayed in a causal loop diagram. In this way, these tools provide a structured and intuitive environment for model development.

The model is organized according to four broad, interacting subsystems: hydrology, ecosystem, sociocultural, and land use/economics. Each subsystem is comprised of a range of physical/social processes which in turn inform and impact the dynamics of the other subsystems. For example, the surface and groundwater hydrology is influenced by climate, vegetation cover, and land use decisions. The availability of water influences decisions about how to allocate the water which in turn defines the economic gains through irrigated agriculture and grazing. Decisions regarding economics and land 
use/water allocation impact the demographics and social network of the region and ultimately feed back to land use decisions in the next time step. A more detailed description of each subsystem and the related interfaces between subsystems is given in Section 3 below.

\section{Subsystem Causal Loop Diagrams}

Causal loop diagrams are used to help communicate the structure of the proposed conceptual model. Causal loop diagramming is a technique for mapping the feedback within and across interacting subsystems [47]. The convention for drawing a causal loop diagram is simple, consisting of a set of variables connected by arrows denoting the causal influence. The arrow of the causal link always points from the independent variable to the dependent variable. Each causal link is assigned a polarity, either positive or negative, to indicate how the dependent variable changes when the independent variable changes (all other variables assumed constant). Below, each subsystem is described and mapped individually as a causal loop diagram. In an attempt to show interaction across subsystems, variables are color coded to their primary subsystem, blue for hydrology, green for ecosystem, red for economics and orange for social/cultural.

\subsection{Hydrology}

\subsubsection{Purpose, Drivers, Outputs, Scope, Connectivity, Key Variables}

The hydrology subsystem causal loop diagram tracks the spatial and temporal distribution of four principal water stocks in each watershed, namely, surface water, groundwater, irrigation conveyance, and soil moisture (Figure 4). The primary climate variables that affect the hydrology in each watershed are temperature and precipitation. Temperature and precipitation are based on Intergovernmental Panel on Climate Change (IPCC) runs, which were downscaled to cover each of the three watersheds (Alcalde, El Rito, and Rio Hondo) in this study. The downscaled runs are adopted from the Bias Corrected and Downscaled World Climate Research Programmer's (WCRP's) Coupled Model Intercomparison Project phase 3 (CMIP3) climate Projections archive [50-51]. Key system outputs of the hydrology subsystem include the availability of water for domestic pumping, irrigation and upland/riparian vegetation uptake. Also of interest is total watershed water yield and delivery of water to downstream users.

\subsubsection{System Function and Causality for Diagram}

Hydrologic connectivity between upland water sources and floodplain valleys downstream in watersheds of northern New Mexico may be important for determining the hydrologic resilience of these watersheds in the face of climate variability. Several studies address in part the connectivity between uplands and valleys, concluding that there is a temporally variable hydrologic connectivity between these two landscapes [52-54]. The hydrology subsystem in this study treats the upland watershed and the irrigated valley separately, but it also looks at key interactions between these two landscapes.

In the uplands, net precipitation is partitioned between surface water runoff, soil moisture, and groundwater recharge. One of the key dynamics in the upland portion of the watershed is the linkage 
between precipitation, soil moisture, and upland vegetation uptake (Figure 4). Upland vegetation uptake is mediated by climate variability as well as by the management of the natural resources (i.e., forest management and grazing decisions). Also of importance in the uplands is the groundwater recharge through preferential flow paths and excess soil moisture infiltration.

In the valleys, water from the uplands is conveyed via stream flow, which in turn is composed of upland runoff and base flow (from groundwater storage). From all the water diverted from streamflow for irrigation (irrigation diversions), a fraction goes back to the stream flow, either as surface return flow (i.e., irrigation tailwater), or as shallow groundwater return flow (from canal and crop seepage), and the remainder becomes crop uptake. Domestic pumping and riparian uptake are the main losses of the groundwater storage component (Figure 4).

Figure 4. Hydrology subsystem causal loop diagram. Blue colored variables are primary to the hydrology subsystem and other colors are primary to other subsystems (green are ecosystem, red are land use/economics, and orange are sociocultural). Black are critical variables integrating across multiple subsystems.

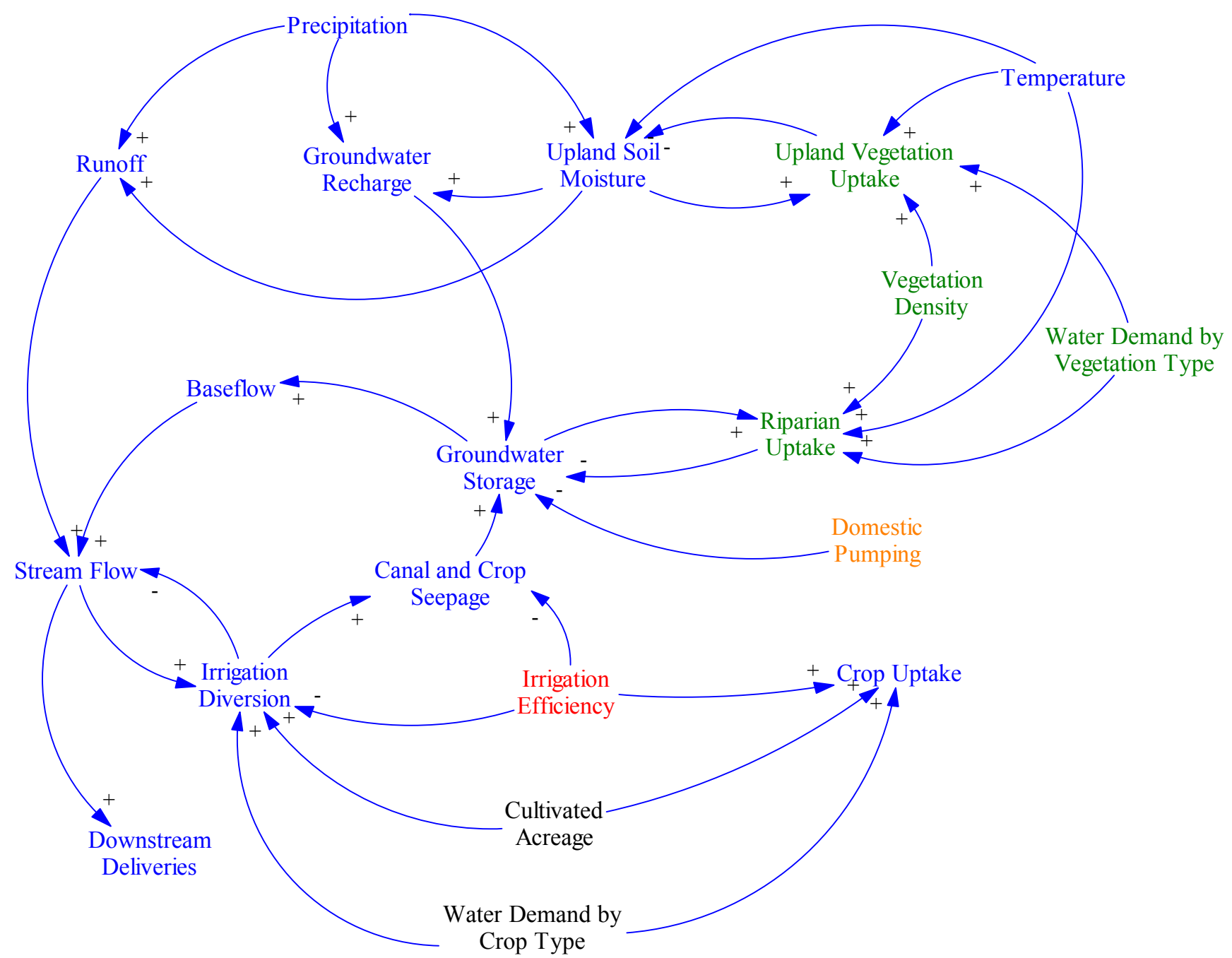




\subsubsection{Interactions with Other Systems}

Throughout northern New Mexico, upstream snow melt watersheds provide runoff to downstream floodplain valleys that are irrigated with acequia irrigation systems. The hydrology of these acequia systems is intrinsically linked to other natural and human elements that include various ecological, economical, and sociocultural aspects. For instance, man-made irrigated landscapes arising from the acequias can perpetuate wetland and riparian habitats by providing wetland habitat, migration corridors, pollution buffer capacity, and stream bank stabilization. Also these acequia systems provide important services like community water supply, crop production, water quality protection, and livestock watering and forage. Land use decisions drive irrigation and domestic pumping demands, in turn impacting surface water flow and interactions with groundwater [53-56]. Operation of the acequia conveyance system with its associated leakages provides another critical ecosystem service in reducing peak flows during snowmelt and increasing river flow during summer and fall low flow periods [29]. Spring snowmelt peaks are diverted into the irrigation system, from which the water percolates to groundwater, is stored underground for weeks to months, and then returns by shallow groundwater flow to streamflow.

\subsection{Ecosystem}

\subsubsection{Purpose, Drivers, Outputs, Scope, Connectivity, Key Variables}

The ecosystem subsystem examines the links between ecosystem services, faunal biodiversity and the vegetation dynamics of the semi-natural and managed landscapes of the floodplain valleys and high elevation watersheds (Figure 5). Ecosystem services as represented by vegetation structure/composition and the associated faunal biodiversity are key outputs of the ecosystem subsystem [57-58]. Vegetation biodiversity is one particularly useful indicator of healthy ecosystem function because previous work enables direct spatial mapping of ecosystem health based on remotely sensed vegetation. 
Figure 5. Ecosystem subsystem causal loop diagram. Green colored variables are primary to the ecosystem subsystem and other colors are primary to other subsystems (blue are hydrology, red are land se/economics, and orange are sociocultural). Black are critical variables integrating across multiple subsystems.

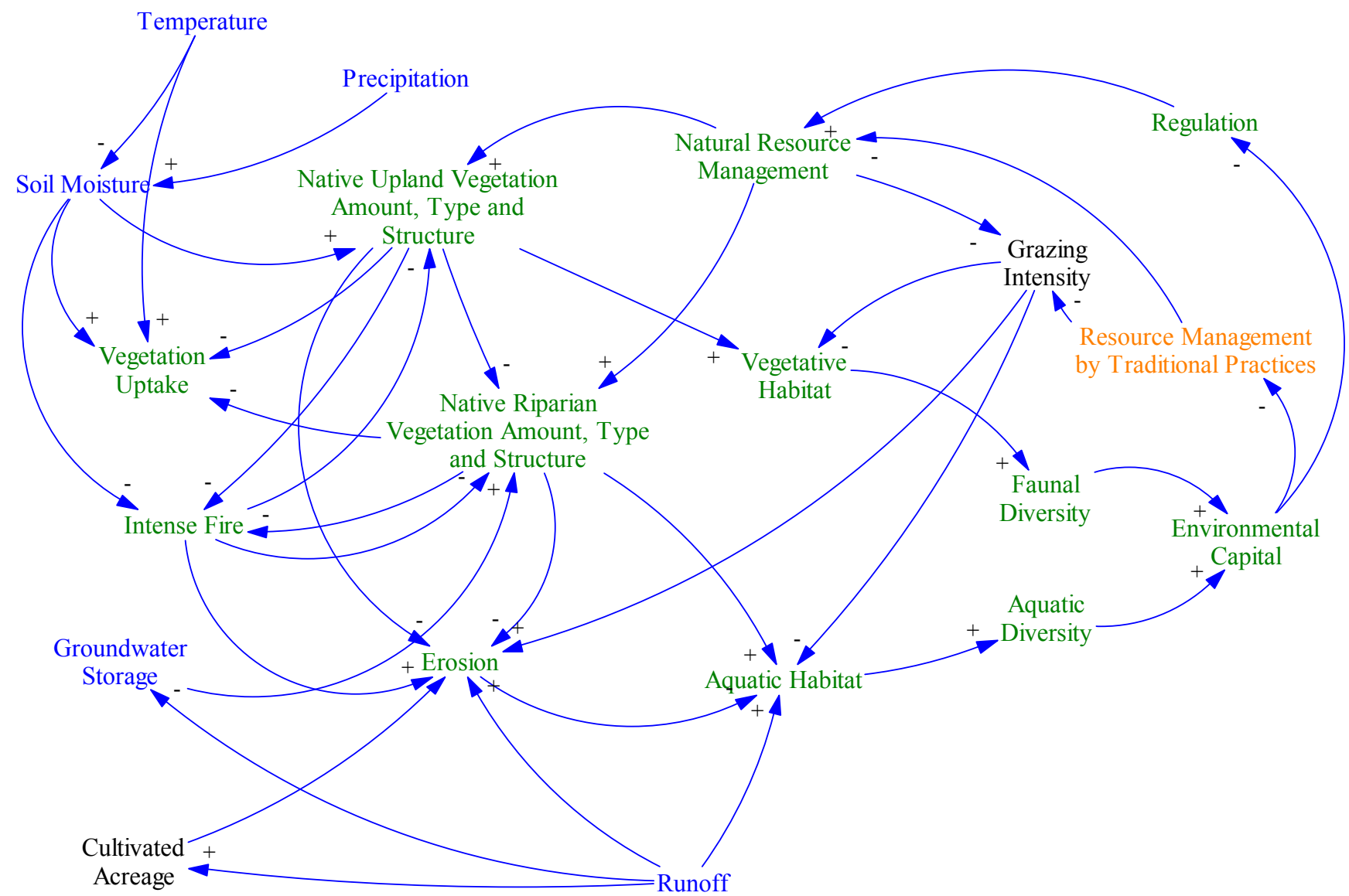

\subsubsection{System Function and Causality for Diagram}

The key dynamic in this subsystem is the vegetative transition as forced by a combination of climate change and land use practices. Flora and fauna are directly tied to the hydrological cycle. Water availability, timing, and abundance dictate vegetation community species, diversity, structure, and productivity. Changes in the hydrological cycle can affect vegetation communities by changing soil properties, germination rates, scouring events, among others. Faunal species are linked through the direct need for water, and the use of vegetation and abiotic factors that comprise the species habitat. Aquatic systems and species are directly affected by flow seasonality and abundance. These organisms can also be affected by regulation of environmental events such as high temperature or large floods. Changes in hydrological regime can also affect the dynamic riparian vegetation alongside the aquatic systems. The riparian areas are focal areas for many vertebrate and invertebrate species and changes in stand composition and structure can change the underlying habitat necessary to support species. A drying transition can establish upland species that are not adapted to hydric soil or inundation. These drying transitions may also encourage establishment of additional non-native phreatophytes that augment existing ones such as saltcedar (Tamarix sp.) and Russian olive (Elaeagnus angustifolia). Changes in precipitation timing and intensity can alter run-off, percolation rates, and erosion which 
can negatively impact upland vegetation community composition and structure, and affect riparian and aquatic communities as sedimentation increases and recharge decreases.

Transitions caused by changes in soil and water availability are reflected in the overall vegetation community composition and structure. Higher temperatures and lower soil moisture challenge existing vegetation and encourage non-native species invasion, which is reinforced by pest infestation and fire. Vegetation diversity may either increase or decrease within these systems. Vegetation communities may transition into more xeric conditions with similar structure, xeric conditions with a change in structure, or mesic conditions with a change in structure [59].

Changes in vegetation composition and structure affect faunal diversity through the food web. For example, changes in seed plants can alter the small mammal and bird fauna that are reliant on these seeds for food. These changes are then reflected upwards into the food web as higher level predators are affected by lower prey abundance.

A system dynamics model will be developed that varies the resultant change in vegetation community and structure incorporating the state and transition model framework [60]. State and transition models are developed for specific ecological sites, and our study will not field test ecological sites at that level of detail. Yet we plan to estimate change in habitat and potential species diversity based on vegetation changes and then use these estimates to quantify the change or resiliency within the system given changes in the transitions and communities.

\subsubsection{Interactions with Other Systems}

Humans benefit from healthy ecosystems and the goods and services that healthy ecosystems provide [57]. These ecosystem services include not only water availability and abundance from the hydrology subsystem, but food, recreational, aesthetic, and cultural value from the flora and fauna the ecosystem provides [58]. The ecology of acequia systems is linked to other natural and human elements that include various hydrological, economical, and sociocultural aspects. Increased faunal and aquatic diversity associated with acequia systems provide important environmental capital for economic, community and natural resource management. Land use decisions based on economics or sociocultural norms can affect habitat and the species that occupy that habitat.

\subsection{Land Use/Economics}

\subsubsection{Purpose, Drivers, Outputs, Scope, Connectivity, Key Variables}

A variety of economic and non-economic characteristics enter into land- and water-use decisions. This section highlights the linkages between individual and community characteristics, economic opportunities, and resource use with a specific focus on resilience and building adaptive capacity. Livestock grazing (a specific kind of land resource use) is described in some detail due to its critical role in linking uplands and acequia communities. The land use/economics subsystem quantifies the market and non-market drivers influencing decisions on land use. External drivers to the subsystem include the basic opportunities and stressors associated with downstream urbanization. These include factors such as jobs, demands for agricultural goods, and real-estate and water values. Outputs are primarily the evolving stocks of market and non-market value accumulated by basin residents and their 
related land use decisions. Such decisions include cropping, livestock grazing and/or the choice to sell/lease land and water.

\subsubsection{System Function and Causality for Diagram}

Land- and water-use decisions are fundamental to the functioning and character of the agro-environmental economies of acequias. In addition to the significant contributions these resources make to local jobs and incomes, they help to forge a community identity through culture and traditions, and through connectivity to the surrounding and embedded ecosystems. Simplified models of economic behavior are usually motivated by such motifs as maximizing profits or long-run return on investment. How applicable are these motifs to individuals comprising an acequia? What other considerations are important to the decision processes? What considerations are instrumental in defining local institutions such as those that govern resource allocation, sharing and use? The enduring nature of many acequia communities attests to qualities of sustainability and capacity to cope with challenging conditions and stresses. What mechanisms or attributes exist for such communities to continue to invest in sustainability? What types and forms of investment are now needed by the community to better prepare for anticipated future conditions and stresses?

Figure 6 shows a causal loop diagram that illustrates key linkages between attributes of acequias, their members, existing economic opportunities, needed investments, and desired outcomes. Outcomes in this case not only include economic viability and sustainability, including jobs and incomes, but also cultural and environmental viability and sustainability, qualities that are also held in prominence within these rural communities. Specifically, crop and livestock decisions and activities determine the extent and intensity of land and water use, leading to both non-economic and economic outcomes. Land use decisions are shaped by prevailing economic conditions, such as product and factor prices, suitability of land to various economic opportunities, and the capabilities and characteristics of the land manager. Water uses and conservation activities are key outcomes that will feed into the hydrological system modeling and also into the ecosystem and sociocultural subsystems.

Livestock grazing is thought to play a critical role in maintaining the socioeconomic fabric of acequia communities; upland ranching and valley farming are often intricately connected. Hypothesized grazing-mediated linkages (both direct and indirect) between uplands and valleys are depicted in Figure 6. Livestock-raising is part of a strong cultural tradition among acequia farmers and as such, has been associated with historical community tipping points. The decision to stay in farming is often linked to a family's ability to graze livestock on public uplands. Grazing management decisions, however, are mostly controlled by public land agencies which have a congressional mandate to manage uplands for multiple uses. Thus, public land policy is possibly the most consequential external driver of livestock grazing activities of acequia communities. Adopted grazing polices also influence vegetation and game animal diversity and density [61]. Vegetation cover in turn influences water production from the watershed.

In addition, a key thrust of studying the socioeconomic system aims at better understanding the determinants of community resilience and sustainability. The causal loop diagram shown in Figure 6 captures community perceptions of resilience and of needed future investments in community adaptive capacity and sustainability. 
Figure 6. Land use/economics subsystem causal loop diagram. Red colored variables are primary to the land use/economics subsystem and other colors are primary to other subsystems (blue are hydrology, green are ecosystem, and orange are sociocultural). Black are critical variables integrating across multiple subsystems.

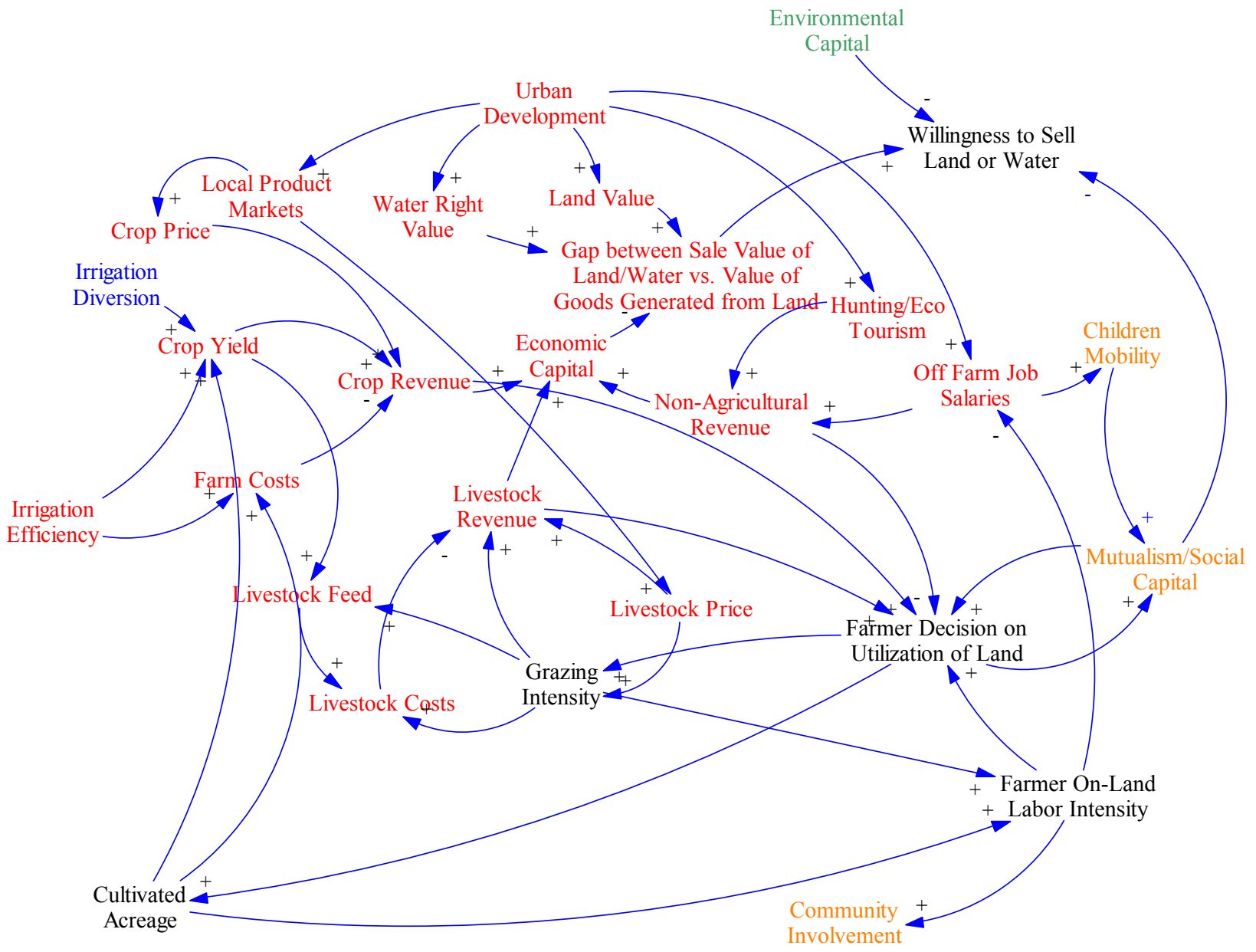

\subsubsection{Interactions with Other Systems}

For the land use/economics subsystem, particular attention is given to the differences and connections between upland watersheds and irrigated valleys. The criteria for land use decisions differ somewhat between the upland forested and often publically held watershed, which can provide for multiple and often simultaneous uses, and the irrigated valleys that are managed privately for both economic and non-economic purposes. Key upland decisions include the extent/type of grazing, hunting, and extraction of fuel wood. Decisions are dependent not only on basic economic drivers but also on non-market drivers as represented by social/cultural/traditional values. Grazing decisions are greatly dependent on cropping decisions as winter forage is often linked to irrigated valley cropping decisions. Cross-system dynamics include regulatory controls on grazing, hunting and fuel wood extraction. Other dynamics link decisions concerning upland land use and its impact on vegetative cover. This in turn has implications for upland hydrology and related ecosystem services (e.g., faunal diversity).

In the irrigated valleys, which include households and irrigated land, residents balance the decisions between local land based options (farming, grazing, etc.), the extent to which they supplement their 
living with an external job or selling off their land or water. This basic decision derives from both the basic economics involved as well as non-market based values that are linked to the sociocultural subsystem. Decisions ultimately influence the number of farms held by traditional families and thus the type and extent of farming in the valley (affecting the hydrology and ecosystem services as noted above).

\subsection{Sociocultural}

\subsubsection{Purpose, Drivers, Outputs, Scope, Connectivity, Key Variables}

This subsystem quantifies the social-cultural-traditional values and their influence on basin land use decisions. The acequias of northern New Mexico are water management institutions with standing as political subdivisions of the state that take surface water out of upland streams by way of diversions and head gates for delivery of water to irrigators and their valley farmlands alongside one or both banks of the stream. These human made ditches function both as physical infrastructure for water conveyance as well as the basis of social organization in terms of water allocation, rules for governance, and the pooling of labor to maintain a common irrigation canal and laterals throughout the floodplain valley. Important external stressors to this system include decisions that regulate land and water use (e.g., grazing permits, water rights). The acequias irrigate by means of gravity flow and divert water only when available with no inputs from fossil fuels, pumping, or other mechanical technology. Most of the benefits of these community-based irrigation systems are the non-market values that influence land use decisions in the basin. By diverting water upstream and distributing it across the relict floodplain, acequias help expand riparian vegetation cover over the valley bottomland. These riparian vegetation communities become ecosystem corridors that provide habitat for diverse animal and plant species, generate ecosystem services, and buffer extreme hydrologic events by recharging groundwater aquifers of the diversion source river.

\subsubsection{System Function and Causality for Diagram}

Key elements of the sociocultural subsystem are crop type and acreage, livestock type and number, and willingness to sell land or water. At the level of the individual irrigators, the acequia farmers themselves make adjustments seasonally in terms of cropping patterns, land use changes, conservation practices, and reductions in livestock if needed. When conditions improve, they may once again expand their investments and attempt to recover or replace any temporary setbacks in production. Many of the irrigators maintain a mixed farm and ranch economy, a traditional lifestyle based not on the production of profit but rather on the preservation of savings [62]. These small-scale farm-ranch operations are a means of maintaining rather than expanding wealth, a way for parents to pass a way of life on to their offspring. From the farmer-rancher standpoint, their agricultural operations are successful as long as they do not create debt. Family income usually depends more on wage labor than on agriculture, but active involvement in an agricultural way of life helps to sustain a sense of cultural identity, attachment to place, social connection and continuity, and personal belonging in a larger community of interest. 
Individual irrigator decisions are tied to community water management and water governance. For governance, irrigators elect three commissioners and a mayordomo (canal manager) who have decision authority and water management autonomy at the local level, a key factor in their ability to adapt to seasonal and climatic changes especially during times of low flows in the stream or reductions of snow pack conditions in the headwaters source. In most watersheds, the acequias are the first diversions at the top of the stream and therefore, the acequia officers can respond and adapt quickly to seasonal changes in streamflow in accordance with their senior or junior rights as applicable. They combine hydrologic and sociocultural strategies encoded in the acequia culture to respond collectively to early snow melt releases in the spring and variable precipitation during the summer months. During times of water scarcity or years of prolonged drought, water delivery arrangements can be modified according to local customs and traditions including: repartimiento (water sharing), auxilio (emergency water), and allocation of sobrantes (surplus waters). Agreements on how to divide the water within and across acequias may be reviewed and altered to fit existing conditions in the stream whether in times of relative abundance or expected shortages. In addition to allocating water and, along with the commissioners, overseeing the maintenance and improvement of the irrigation infrastructure, the mayordomo resolves disputes that may arise between parciantes over water. The ability of the acequia community to recover from natural systems changes and other stressors in the environment is an indicator of system resilience and sustainability.

Acequia functionality and productivity in the floodplain valleys are inextricably connected to the health of the upland snowmelt watershed. Irrigators with livestock depend on access to the grazing areas in the forests as summer pastures while they grow alfalfa or other hay crops on their irrigated farmlands in the valley for use as winter feed stock. There is also upland grazing of public (Bureau of Land Management) lands in winter, reducing the number of animals actually held in the valleys. Mountain pastures were formerly land grant resources for use as commons by the early settlers but are now administered and regulated by Forest Service managers as public domain for multiple uses not limited to the grazing of livestock. Water rights, on the other hand, are administered by the New Mexico Office of the State Engineer under the doctrine of prior appropriation prevalent in the Western States. Adjudications of water rights on the streams of New Mexico are underway in federal and state district courts but have proven costly in terms of litigation and other transaction costs inherent in the adversarial process of lawsuits that attempt to quantify water rights and establish a priority date of beneficial use for each individual water right.

\subsubsection{Interactions with Other Systems}

This subsystem captures the struggle between the traditional sociocultural norms and the influence of downstream urbanization. A key feature is the degree of family and community cohesiveness. Preservation of traditional norms requires adoption of these norms by successive generations while resisting the pressure of jobs and changing material expectations. Cohesion is a dynamic process rather than a fixed trait, to allow for the combination of traditional knowledge and practice with the kind of flexibility and even innovation that characterizes resilience over time. The causal loop diagram is intended to capture the interface between subsistence practices and cultural norms, beliefs, and values, and also show how internal conflict is mediated within a fundamentally cooperative 
structure (Figure 7). Community cohesiveness depends on traditional families staying on their farms. More cohesion leads to cooperation in planning, shortage sharing in times of drought and cooperation in maintaining community infrastructure. This cooperation leads to improved system efficiencies and resilience to fragmentation of the community. Participation in parish activities, seasonal and life cycle celebrations, and school events all help hold community together. These values are dynamically linked to their ability to make a living on the land as well as the year to year availability of water.

Figure 7. Sociocultural subsystem causal loop diagram. Orange colored variables are primary to the sociocultural subsystem and other colors are primary to other subsystems (blue are hydrology, green are ecosystem, and red are land use/economics). Black are critical variables integrating across multiple subsystems.

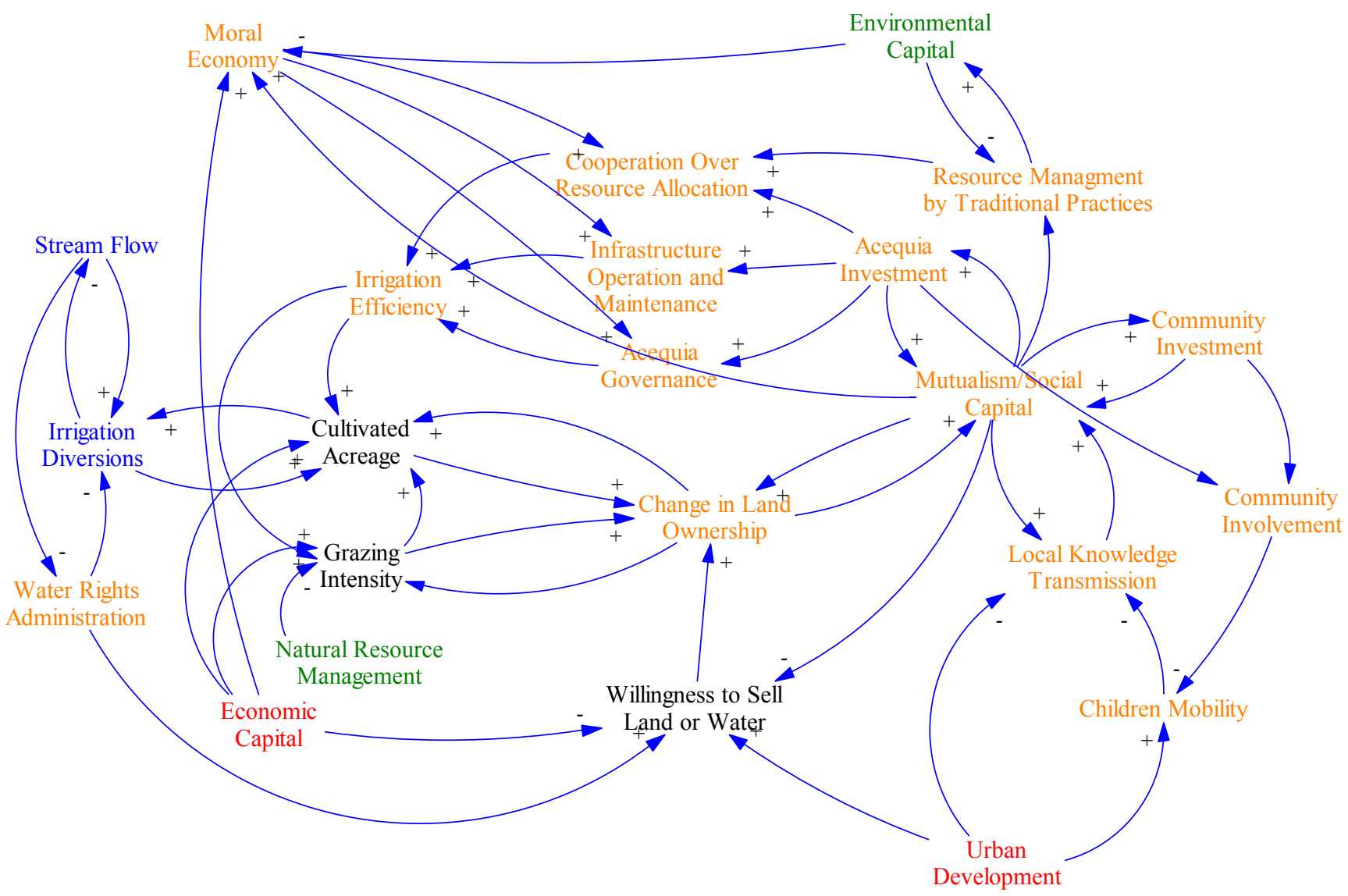

Mutualism encompasses cultural values as well as specific practices. Operationally, it can be unpacked into potentially quantifiable behaviors such as participation in key traditional (and some more recent) institutions typically found in modern acequia communities: the acequia itself; local parish (involving multiple ritual as well as secular activities in which women may play leading roles); the community land grant; mutual aid societies; livestock grazing association; volunteer fire department, the community library, rural health clinic and so on. Mutualism and social capital capture the presence and degree of familial/individual participation in these organizations $[12,45]$.

Local knowledge transmission refers to the ways in which continuity of agricultural and associated practices is passed down in families. Recruitment and training of the next generation of irrigators/farmers/ranchers is a crucial component of acequia agriculture as a sustainable adaptation. 
Individuals participate in these activities as members of landholding families. Kinship and social density (multiple ways in which individuals are connected in a small community) are also critical measures of family "cohesion" and community [4].

\section{Future Directions}

A key success of our project to date is the bridging of disciplinary divides through use of causal loop diagrams. These causal loop diagrams will be used to develop the system dynamics model that brings together the subsystems. The modeling effort will include three key steps: quantification of the causal loop diagrams (conceptual model) within a system dynamics architecture, work with stakeholders to calibrate the model, and finally simulation of future scenarios.

A simulation model will be formulated by mapping the causal loop diagrams to the conventional stock and flow structure of system dynamics [47]. That is, the causality and decision structure captured in the causal loop diagram/conceptual model is quantified by a set of interacting stocks (system state variables such as population, irrigated acres, head of cattle grazed) and flows characterizing the rate of movement between stocks). Key system parameters, rate functions, and initial conditions that define and regulate the iterations among variables are specified through use of existing physical and social data as well as through the conduct of written surveys and personal interviews. Besides continual vetting of the model with acequia community stakeholders, calibration and verification of the model is pursued through comparisons drawn with key historical time series. An example of such a documented data set is shown in Figure 8. Over 41 years land use along the Alcalde Acequia has changed with increases in residential areas and changes from cash and food crops to pasture grass and alfalfa [3]. The goal is to capture this and other such trends in our simulation model for the Alcalde area. Other expected data include population numbers, livestock type and numbers, land values, water rights, land ownership patterns, and other quantifiable data.

The actual model will be put together in a single unified system dynamics model. Stakeholders have been critical for development of the causal loop diagrams. Once the model is functioning, we will rely on stakeholders to vet and calibrate the model. Finally we will explore scenarios to characterize sustainability based on a tipping point approach and testing the major drivers of population growth and climate change. We will identify the types and amounts of change in the communities and ecosystems that lead to major and irreversible impacts on hydrology, ecosystem, land use/economics and sociocultural subsystems. The results from this interdisciplinary stakeholder guided model will then be fed back to the stakeholder communities to help the communities enhance their own sustainability.

In addition to community-scale modeling, project results will be incorporated into larger scale modeling. Given that there are over 800 acequia systems in the northern reaches of the Rio Grande, efforts will be made to extend the acequia modeling from Alcalde, Rio Hondo, and El Rito to the Upper Rio Grande Basin. Based on understanding gained from these three study communities, models and system parameters will be transferred as appropriate to simulate behavior of other acequia systems. Previous work has integrated surface and groundwater modeling with system dynamics in a basin wide model [63]. To the extent possible, site specific information on populations, grazing, cropping, etc., will be gathered and integrated into the basin-wide model. Once complete, the basin-wide model will be used to evaluate alternative future climate and urbanization scenarios. For these different scenarios 
various adaption and mitigation strategies will be explored. The resulting simulations will provide insight into basin-wide acequia community response in terms of irrigated acreage, cropping/grazing decisions, population change, and ecosystem evolution.

Figure 8. Land use changes in an acequia irrigated community [3].

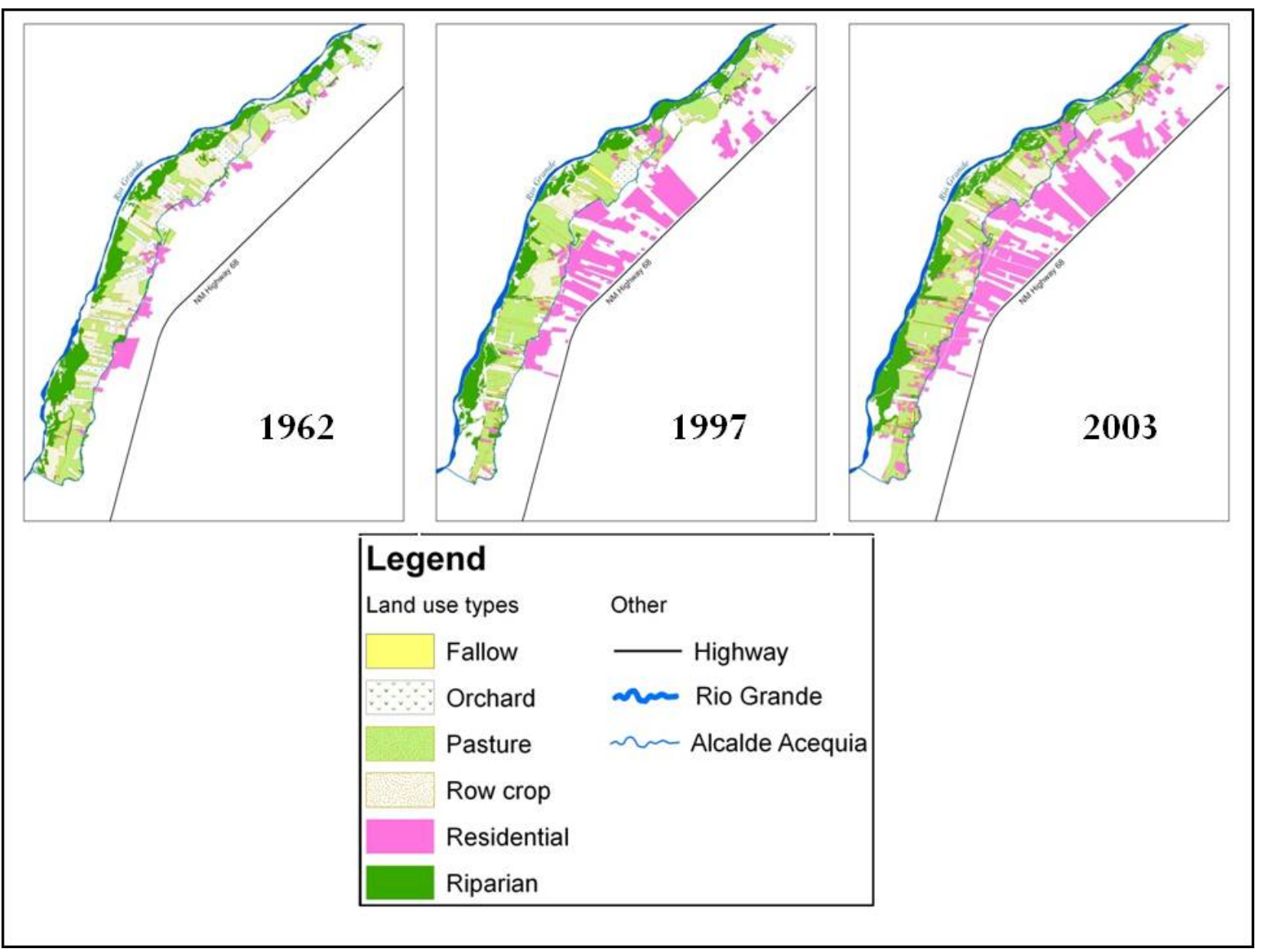

\section{Acknowledgments}

This study was funded in part by the New Mexico Agricultural Experiment Station and National Science Foundation grants \#814449 New Mexico EPSCoR, and \#1010516 Dynamics of Coupled Natural and Human Systems. We appreciate the assistance with graphics provided by Hamid Rad.

\section{Conflict of Interest}

The authors declare no conflict of interest.

\section{References}

1. Ackerly, N.W. A Review of the Historic Significance and Management Recommendations for Preserving New Mexico's Acequia Systems; Prepared by Dos Rios Consultants Inc; Historic Preservation Division: Santa Fe, NM, USA, 1996. 
2. Cox, M.; Ross, J.M. Robustness and vulnerability of community irrigation systems: The case of the Taos valley acequias. J. Environ. Econ. Manag. 2011, 61, 254-266.

3. Ortiz, M.A.; Brown, C.; Fernald, A.; Baker, T.; Creel, B.; Guldan, S. Land use change impacts on acequia water resources in northern New Mexico. J. Contemp. Water Res. Edu. 2007, 137, 47-54.

4. Rivera, J.A. Acequia Culture: Water, Land, and Community in the Southwest; University of New Mexico Press: Albuquerque, NM, USA, 1998.

5. Smith, J.B.; Wagner, C. Scenarios for the National Commission on Energy Policy; Stratus Consulting; Boulder, CO, USA, 2006.

6. U.S. Census Bureau. State and County Quick Facts. Available online: http://quickfacts. census.gov/qfd/states/35000.html (accessed on 10 October 2011).

7. Pulido-Bosch, A.; Ben Sibh, Y. Centuries of artificial discharge on the southern edge of the Sierra Nevada (Granada, Spain). Environ. Geol. 1995, 26, 57-63.

8. Eastman, C.; Gray, J.R. Community Grazing: Practice and Potential in New Mexico; University of New Mexico Press: Albuquerque, NM, USA, 1987.

9. Hutchins, W. The community acequia: Its origins and development. Southwestern Hist. Quart. 1928, 31, 261-284.

10. Simmons, M. Spanish irrigation practices in New Mexico. New Mex. Hist. Rev. 1972, 47, $135-150$.

11. Crawford, S. Mayordomo: Chronicle of an Acequia in Northern New Mexico; University of New Mexico Press: Albuquerque, NM, USA, 1988.

12. Rodriguez, S. Acequia: Water Sharing, Sanctity, and Place; School for Advanced Research Press: Santa Fe, NM, USA, 2006.

13. Alam, M.M.; Bhutta, M.N. Comparative evaluation of canal seepage investigation techniques. Agr. Water Manage. 2004, 66, 65-76.

14. Singh, R.; Kroes, J.G.; van Dam, J.C.; Feddes, R.A. Distributed ecohydrological modelling to evaluate the performance of irrigation system in Sirsa district, India: I. Current water management and its productivity. J. Hydrol. 2006, 329, 692-713.

15. Fernald, A.G.; Baker, T.T.; Guldan, S.J. Hydrologic, riparian, and agroecosystem functions of traditional acequia irrigation systems. J. Sustain. Ag. 2007, 30, 147-171.

16. Willis, T.M.; Black, A.S.; Meyer, W.S. Estimates of deep percolation beneath cotton in the Macquarie Valley. Irrig. Sci. 1997, 17, 141-150.

17. Asare, D.K.; Sitze, D.O.; Monger, C.H.; Sammis, T.W. Impact of irrigation scheduling practices on pesticide leaching at a regional level. Agr. Water Manage. 2000, 43, 311-325.

18. Mankin, K.R.; Koelliker, J.K. A hydrologic balance approach to saline seep remediation design. Appl. Eng. Agr. 2000, 16, 129-133.

19. Ochoa, C.G.; Fernald, A.G.; Guldan, S.J.; Shukla, M.K. Deep percolation and its effects on shallow groundwater level rise following flood irrigation. Trans. ASABE 2007, 50, 73-81.

20. Schmidt, K.D.; Sherman. I. Effect of irrigation on groundwater quality in California. J. Irrigat. Drain. Eng. 1997, 113, 16-29.

21. Drost, B.W.; Cox, S.E.; Schurr, K.M. Changes in Ground-Water Levels and Ground-Water Budgets, from Predevelopment to 1986, in Parts of the Pasco Basin, Washington; U.S. Department of the Interior, U.S. Geological Survey: Tacoma, WA, USA, 1997. 
22. Harvey, E.F.; Sibray, S.S. Delineating groundwater recharge from leaking irrigation canals using water chemistry and isotopes. Ground Water 2001, 39, 408-421.

23. Maurer, D.K. Ground-Water Flow and Numerical Simulation of Recharge from Streamflow Infiltration Near Pine Nut Creek, Douglas County, Nevada; Water Resour. Invest. Rep. 02-4145; U.S. Geological Survey: Carson City, NE, USA, 2002.

24. Fernald, A.G.; Guldan, S.J. Surface water-groundwater interactions between irrigation ditches, alluvial aquifers, and streams. Rev. Fish. Sci. 2006, 14, 79-89.

25. Helmus, A.M.; Fernald, A.G.; VanLeeuwen, D.M.; Abbott, L.B.; Ulery, A.L.; Baker, T.T. Surface water seepage effects on shallow ground-water quality along the Rio Grande in northern New Mexico. J. Am. Water Resour. Assoc. 2009, 45, 407-418.

26. Kendy, E.; Bredehoeft J.D. Transient effects of groundwater pumping and surface-waterirrigation returns on streamflow. Water Resour. Res. 2006, 42, 1-11.

27. Wissmar, R.C. Riparian corridors of Eastern Oregon and Washington: Functions along lowland-arid to mountain gradients. Aquat. Sci. 2004, 6, 373-387.

28. Peck, D.E.; Lovvorn, J.R. The importance of flood irrigation in water supply to wetlands in the Laramie Basin, Wyoming, USA. Wetlands 2001, 3, 370-378.

29. Fernald, A.G.; Cevik, S.Y.; Ochoa, C.G.; Tidwell, V.C.; King, J.P.; Guldan, S.J. River hydrograph retransmission functions of irrigated valley surface water-groundwater interactions. J. Irrigat. Drain. Eng. 2010, 136, 823-835.

30. Hurd, B.H.; Coonrod, J. Climate change risks New Mexico's waterways: Its byways and its flyways. Water Resour. Impact 2008, 10, 5-11.

31. Ward, F.A.; Pulido-Velasquez, M. Water conservation in irrigation can increase water use. P. Natl. Acad. Sci. USA 2008, 25, 18215-18220.

32. Rivera, J.A. Irrigation communities of the upper Rio Grande bioregion: Sustainable resource use in the global context. Nat. Resour. J. 1996, 36, 491-520.

33. Bokum, C. Implementing the public welfare requirement in New Mexico's water code. Nat. Resour. J. 1996, 36, 681-706.

34. Siy, R.Y. Community Resource Management: Lessons from the Zanjeras; University of Philippines Press: Quezon City, Philippines, 1982.

35. Ostrom, E. Crafting Institutions for Self-Governing Irrigation Systems; Institute for Contemporary Studies: San Francisco, CA, USA, 1992.

36. Yan Tang, S. Institutions and Collective Action: Self-Governance in Irrigation; Institute for Contemporary Studies: San Francisco, CA, USA, 1992.

37. Boelens, R.; Dávila, G.; Menchú, R. Searching for Equity: Conceptions of Justice and Equity in Peasant Irrigation; Van Gorcum and Co.: Assen, The Netherlands, 1998.

38. Groenfeldt, D. Multifunctionality of agricultural water: Looking beyond food production and ecosystem services. Irrig. Drain. 2006, 55, 73-83.

39. Peña, D. Cultural landscapes and biodiversity: The ethnoecology of an upper Río Grande watershed commons. In La Gente: Hispano History and Life in Colorado; De Baca, V.C., Ed.; Colorado Historical Society: Denver, CO, USA, 1998; pp. 241-271.

40. Nocera, J.J.; Dawe, K.L. Managing for habitat heterogeneity in grassland agro-ecosystems influences the abundance of masked shrews. J. Sustain. Agr. 2008, 32, 379-392. 
41. Krzysik, A.J. Biodiversity in Riparian Communities and Watershed Management. In Watershed Planning and Analysis in Action; Proceedings of the 1990 Watershed Management Symposium, Durango, CO, USA, 9-11 July 1990; Riggins, R.E., Jones, E.B., Singh, R., Rechard, P.A., Eds.; American Society of Civil Engineers: New York, NY, USA, pp. 533-548.

42. Allen, D.R.; Marlow, C.B. Effects of Cattle Grazing on Shoot Population Dynamics of Beaked Sedge. In Proceedings of the Symposium on Ecology and Management of Riparian Shrub Communities, Sun Valley, ID, USA, 29-31 May 1991; U.S. Forest Service General Technical Report INT-289; Clary, W.P., McArthur, E.D., Bedunah, D., Wambolt, C.L., Eds.; Intermountain Research Station: Ogden, Utah, USA, pp. 89-91.

43. New Mexico Department of Game and Fish. Comprehensive Wildlife Conservation Strategy for New Mexico; New Mexico Department of Game and Fish: Santa Fe, NM, USA, 2006.

44. Van Ness, J.R. Series Editor, New Mexico Land Grant Series, University of New Mexico Press. Personal communication, 1987.

45. Van Ness, J.R. Hispanos in Northern New Mexico, The Development of Corporate Community and Multicommunity; AMS Press, Inc.: New York, NY, USA, 1991.

46. Kutsche, P.; Van Ness, J.R. Cañones, Values Crisis, and Survival in a Northern New Mexico Village; UNM Press: Albuquerque, NM, USA, 1981.

47. Sterman, J.D. Business Dynamics, Systems Thinking and Modeling for a Complex World; McGraw-Hill: Boston, MA, USA, 2000.

48. Tidwell, V.C.; Van den Brink, C. Cooperative modeling: Linking science, communication and ground water planning. Ground Water 2008, 46, 174-182.

49. Powersim Software. Available online: http://www.powersim.com/ (accessed on 12 March 2012).

50. Maurer, E.P.; Brekke, L.; Pruitt, T.; Duffy, P.B. Fine-resolution climate projections enhance regional climate change impact studies. Eos Trans. AGU 2007, 88, 504.

51. Maurer, E.P.; Hidalgo, H.G.; Das, T.; Dettinger, M.D.; Cayan, D.R. The utility of daily large-scale climate data in the assessment of climate change impacts on daily streamflow in California. Hydrol. Earth Syst. Sci. Discuss 2010, 14, 1125-1138.

52. Devito, K.J.; Creed, I.F.; Fraser, C.J.D. Controls on runoff from a partially harvested aspen forested headwater catchment, Boreal Plain, Canada. Hydrol. Process. 2005, 19, 3-25.

53. Jencso, K.G.; McGlynn, B.L.; Gooseff, M.N.; Wondzell, S.M.; Bencala, K.E.; Marshall, L.A. Hydrologic connectivity between landscapes and streams: Transferring reach- and plot-scale understanding to the catchment scale. Water Resour. Res. 2009, 45, 1-16.

54. Ocampo, J.C.; Syvalpan, M.; Oldham, C. Hydrological connectivity of upland-riparian zones in agricultural catchments: Implications for runoff generation and nitrate transport. J. Hydrol. 2006, 331, 643-658.

55. Arumí, J.L.; Rivera, D.; Holzapfel, E.; Boochs, P.; Billib, M.; Fernald, A. Effect of irrigation canal network on surface and groundwater connections in the lower valley of the Cachapoal River, Chile. Chil. J. Agr. Res. 2009, 69, 12-20.

56. Fernald, A.G.; Wigington, P.J., Jr.; Landers, D.H. Transient storage and hyporheic flow along the Willamette River, Oregon: Model estimates and field measurements. Water Resour. Res. 2001, 37, 1681-1694. 
57. Millennium Ecosystem Assessment. Ecosystems and Human Well-Being: Our Human Planet: Summary for Decision Makers; Island Press: Washington, DC, USA, 2005.

58. Boykin, K.G.; Thompson, B.C.; Deitner, R.A.; Schrupp, D.; Bradford, D.; O’Brien, L.; Drost, C.; Propeck-Gray, S.; Rieth, W.; Thomas, K.; et al. Chapter 3. Predicted Animal Habitat Distributions and Species Richness. In Southwest Regional Gap Analysis Final Report; Prior-Magee, J.S., Ed.; U.S. Geological Survey, Gap Analysis Program: Moscow, ID, USA, 2005.

59. Stromberg, J.C.; Lite, S.J.; Dixon, M.D. Effects of stream flow patterns on riparian vegetation of a semiarid river: Implications for a changing climate. River Res. and Appl. 2010, 26, 712-729, doi:10.1002/rra.1272. Available online: http://onlinelibrary.wiley.com/doi/10.1002/rra.1272/pdf (accessed on 12 March 2012).

60. Briske, D.D.; Fuhlendorf, S.D.; Smeins, F.E. State-and-transition models, thresholds, and rangeland health: A synthesis of ecological concepts and perspectives. Rangeland Ecol. Manag. 2005, 58, 1-10.

61. Cibils, A.F.; Miller, J.A.; Encinias, A.M.; Boykin, K.G.; Cooper, B.F. Monitoring heifer grazing distribution at the Valles Caldera National Preserve. Rangelands 2008, 30, 19-23.

62. Eastman, C.A. Economics of Small-Scale Irrigated Agriculture in Taos County. M.S. Thesis, New Mexico State University, Las Cruces, NM, USA, 1995.

63. Roach, J.; Tidwell, V. A compartmental-spatial system dynamics approach to ground water modeling. Ground Water 2009, 47, 686-698.

(C) 2012 by the authors; licensee MDPI, Basel, Switzerland. This article is an open access article distributed under the terms and conditions of the Creative Commons Attribution license (http://creativecommons.org/licenses/by/3.0/). 